Annals of Warsaw University of Life Sciences - SGGW

Land Reclamation No 45 (2), 2013: 183-192

(Ann. Warsaw Univ. of Life Sci. - SGGW, Land Reclam. 45 (2), 2013)

\title{
Influence of the rotation of principal stress directions on undrained shear strength
}

\author{
GRZEGORZ WRZESIŃSKI, ZBIGNIEW LECHOWICZ \\ Department of Geotechnical Engineering, Warsaw University of Life Sciences - SGGW
}

\begin{abstract}
Influence of the rotation of principal stress directions on undrained shear strength. The paper presents the results of research on natural cohesive soil carried out in the Hollow Cylinder Apparatus (HCA). The main goal of this study was to determine the values of undrained shear strength at different angle of the rotation of principal stress directions. The research were carried out with anisotropic consolidation and shearing in undrained conditions (CAU) on cohesive soil with overconsolidation ratio (OCR) equals 4 and plasticity index $\left(I_{p}\right)$ about $77 \%$. The results of laboratory tests allow to assess the influence of the rotation of principal stress directions on undrained shear strength.
\end{abstract}

Key words: undrained shear strength, Hollow Cylinder Apparatus, cohesive soils, rotation of principal stress directions

\section{INTRODUCTION}

The rotation of principal stress directions is a common phenomenon that occurs in the subsoil as a result of the construction of structures such as embankments, excavations, tunnels or pad foundations. This occurs when the growth of principal stress directions $\Delta \sigma_{1}, \Delta \sigma_{2}, \Delta \sigma_{3}$ do not coincide with the directions of the principal stresses incurred during consolidation $\sigma_{1}, \sigma_{2}, \sigma_{3}$ (Hight et al. 1983). The effect of this phenomenon in the subsoil is the development of zones with different values of undrained shear strength, which are assigned different values of the angle of rotation of principal stress directions $\alpha$ during the soil structure failure.

The simplification generally is adopted that along the potential slip surface the same undrained shear strength is mobilized. In reality it does not reflect the facts. During determination of the geotechnical parameters, it should be aware that subsoil characterizes anisotropic mechanical properties. The use of undrained shear strength values determined at a specific angle of rotation of principal stress directions may lead to overestimation or underestimation of undrained shear strength, and thus may lead to failure.

One way to determine the change in the undrained shear strength due to changes in the load surface is numerical analysis (Neher et al. 2002, Wrzesiński and Lechowicz 2012) with the use of finite element method. The practical significance of anisotropy is illustrated in Figure 1 by considering an embankment constructed on soft subsoil (Jardine and Menkiti 1999).

Although, the importance of the mechanical anisotropy of subsoils has long been recognized in geotechnical engineering (Bjerrum 1973, Jardine and Smith 1991, Lin and Penumadu 2005, Nishimura et al. 2007, Kiziewicz and Lechowicz 2013), influence of the rotation 


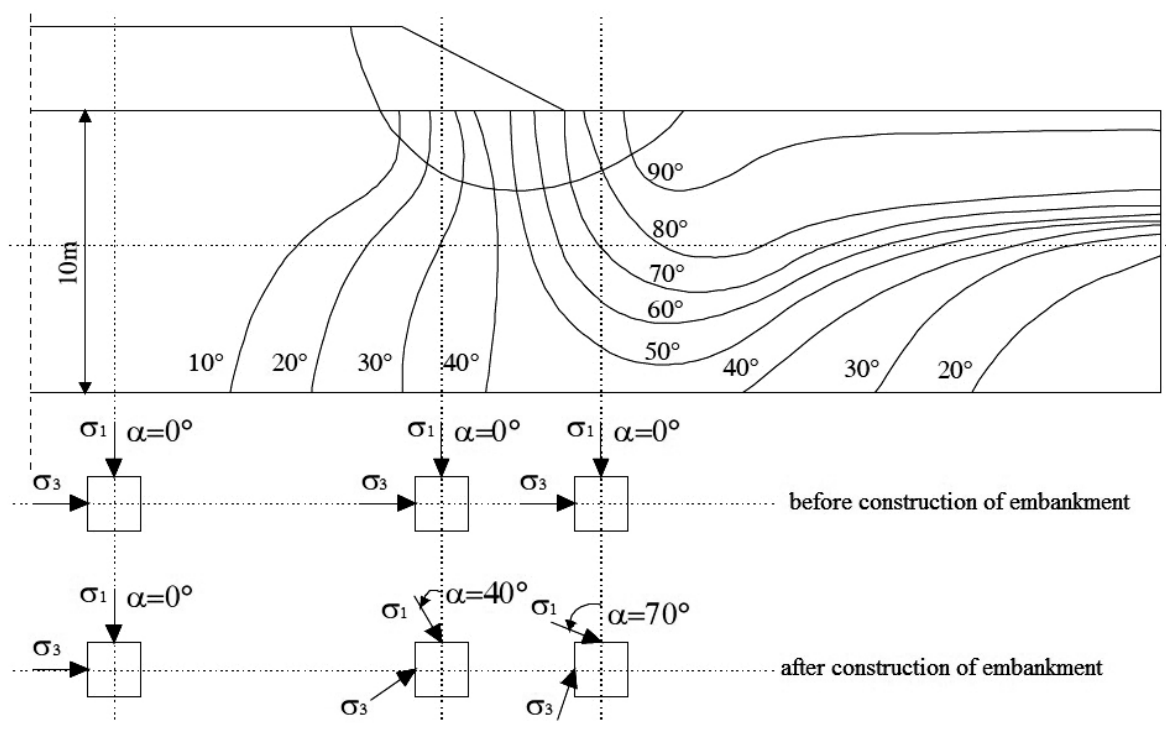

FIGURE 1. Contours of particular values of the rotation of principal stress directions under an embankment on soft clay from non-linear analysis (Jardine and Menkiti 1999)

of principal stress directions on shear strength is not sufficiently recognized. The main reason is the lack of clearly defined methods that take into account the change in the strength due to the change in the angle $\alpha$. Solution to this problem would be to use the right combination of undrained shear strength values obtained from the tests for different zones of the slip surface i.e. triaxial compression (TC), direct simple shear test (DSS), triaxial extension (TE) - Figure 2.
Most of the existing empirical formulas describing the undrained shear strength distribution take into account three zones in subsoil (TC, DSS, TE). Based on these zones Ladd (1985) proposed equation describing the relationship between the normalized undrained shear strength and overconsolidation ratio:

$$
\frac{\tau_{f u}}{\sigma^{\prime} v}=S \cdot(O C R)^{m}
$$

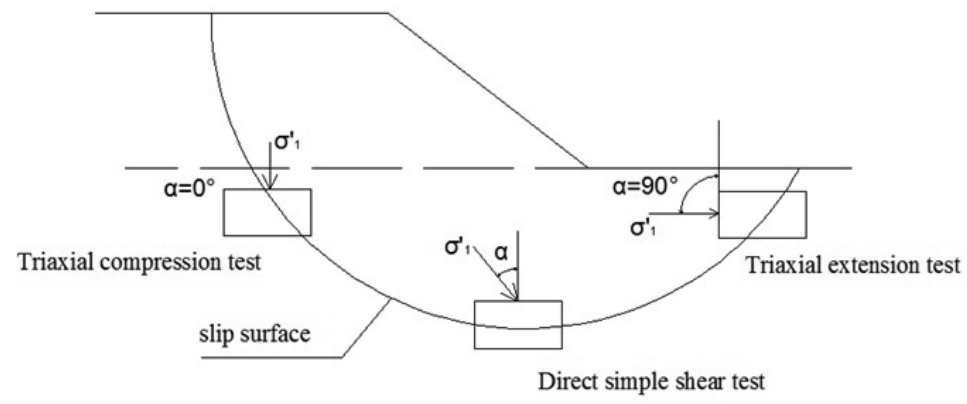

FIGURE 2. Subsoil failure mechanisms in different zones of potential failure surface under embankment (Zdravković et al. 2002) 
where:

$S$ - normalized undrained shear strength for normally consolidated soil, $\sigma^{\prime}{ }_{v}-$ vertical effective stress, OCR - overconsolidation ratio, $m$ - empirical coefficient expressing the slope of correlation between $\log \left(\tau_{f u} / \sigma_{v}{ }_{v}\right)$ and $\log (\mathrm{OCR})$.

One of the laboratory devices that allows to determine the undrained shear strength at the specific value of the angle of rotation of principal stress directions is the Hollow Cylinder Apparatus (HCA). In HCA soil samples in the shape of a hollow cylinder are tested. Forces and pressures applied to the hollow cylindrical sample induced in its elements are illustrated in Figure 3. The sample is exposed to axial load $(F)$ and torque $\left(M_{T}\right)$ as well as internal pressure $\left(p_{i}\right)$ and external pressure $\left(p_{o}\right)$. These four stress components induce in the sample vertical stress $\left(\sigma_{z}\right)$, circumferential stress $\left(\sigma_{\theta}\right)$, radial stress $\left(\sigma_{r}\right)$ and torsional shear stress $\left(\tau_{z \theta}\right)$. In a general case, the stresses will not be uniform across the wall and to consider the hollow cylinder specimen as an element it is necessary to work in terms of average stresses: $\bar{\tau}_{z \theta}, \bar{\sigma}_{z}, \bar{\sigma}_{r}, \bar{\sigma}_{\theta}$.

The Hollow Cylinder Apparatus through the applied torsion mechanism maintains constant values of the angle of the rotation of principal stress directions $\alpha$ and the intermediate principal stress parameter $b$ according to the equation:

$$
b=\frac{\sigma_{2}-\sigma_{3}}{\sigma_{1}-\sigma_{3}}
$$

where:

$\sigma_{1}-$ major principal stress, $\sigma_{2}$-intermediate principal stress, $\sigma_{3}-$ minor principal stress.

Engineering works cause the ground to experience stress conditions where $\alpha$ can vary continously between $0^{\circ}$ and $90^{\circ}$ while parameter $b$ can range between 0
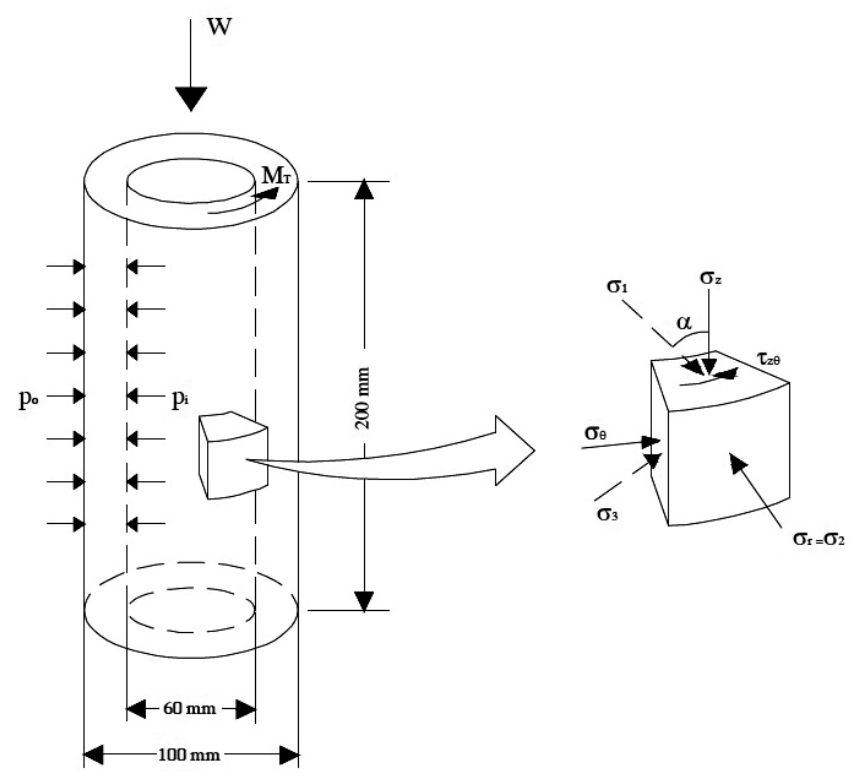

FIGURE 3. Diagram of the soil sample tested in the Hollow Cylinder Apparatus (www.wfi.co.uk) 
and 1. The Hollow Cylinder Apparatus configuration allows such conditions to be studied.

The Hollow Cylinder Apparatus is a definite advantage over the traditional triaxial apparatus used to determine the strength parameters of soil. The ability to vary $\alpha$ continuously between $0^{\circ}$ and $90^{\circ}$, and $b$ between 0 and 1, allowed a wide range of engineering problems to be considered that could not be simulated in undrained conditions (CAU) on cohesive soil with overconsolidation ratio (OCR) equals 4 and plasticity index $\left(I_{p}\right)$ about $77 \%$. The soil samples were taken from the excavation of Copernicus Science Centre station of the II underground line in Warsaw. The research of physical properties has shown that tested soil is firm clay. Index properties of tested soil are presented in Table 1.

TABLE 1. Index properties of tested soil

\begin{tabular}{|l|c|c|c|c|c|c|c|}
\hline $\begin{array}{l}\text { Type } \\
\text { of soil } \\
\text { EN ISO } \\
14688-1\end{array}$ & $\begin{array}{c}\text { Overcon- } \\
\text { solidation } \\
\text { ratio } \\
\text { OCR [-] }\end{array}$ & $\begin{array}{c}\text { Effective } \\
\text { vertical } \\
\text { stress } \\
\sigma^{\prime}{ }_{v}[\mathrm{kPa}]\end{array}$ & $\begin{array}{c}\text { Water } \\
\text { content } \\
w_{n}[\%]\end{array}$ & $\begin{array}{c}\text { Liquid } \\
\text { limit } \\
w_{L}[\%]\end{array}$ & $\begin{array}{c}\text { Plastic } \\
\text { limit } \\
w_{p}[\%]\end{array}$ & $\begin{array}{c}\text { Plasticity } \\
\text { index } \\
I_{p}[\%]\end{array}$ & $\begin{array}{c}\text { Liquidity } \\
\text { index } \\
I_{L}[-]\end{array}$ \\
\hline $\mathrm{Cl}$ & 4 & 310 & 30.4 & 112.9 & 35.3 & 77.6 & -0.06 \\
\hline
\end{tabular}

triaxial or plain strain apparatus. Moreover, the only possibility of dependence of undrained shear strength on the angle of the rotation of principal stress directions in the triaxial apparatus is to prepare the samples that have been cut at an angle to the direction of the grain and soil particles. However, in this case, it would be impossible to consolidate the sample in conditions equivalent to in situ ones, because the axis of consolidation in situ does not coincide with the directions controlled in triaxial apparatus. Moreover, the slope of the anisotropic properties of the sample relative to the directions of deformation controlled in triaxial apparatus causes that on rigid elements are generated bending moments, which are neither controlled nor measurable (Molenkamp 1998, Nishimura 2005).

\section{MATERIAL AND METHODS}

The research were carried out with anisotropic consolidation and shearing in
Tests were performed on the soil samples in the Hollow Cylinder Apparatus. Particular samples were tested at a different angle of the rotation of principal stress directions $\alpha: 0^{\circ}, 30^{\circ}, 45^{\circ}, 60^{\circ}$ and $90^{\circ}$. The studies were performed in the following stages: flushing, saturation, consolidation, change of intermediate principal stress parameter $b$, change of the angle $\alpha$ between the major principal stress direction and the vertical one and finally shearing in undrained conditions.

The study started from the flushing i.e. removed the air and gases having the largest size from the sample and hoses. The saturation using back pressure method was the next stage. This stage lasted until the value of the Skempton's parameter $B$ was more than 0.95 (Lipiński and Wdowska 2010). After that the anisotropic consolidation was performed. The value of $K_{0}$ during consolidation process was equal to 1.06 , so the effective horizontal stress $\sigma^{\prime}{ }_{h}$ was equal to $329 \mathrm{kPa}$, and the effective vertical stress 
$\sigma^{\prime}{ }_{v}$ was equal to $310 \mathrm{kPa}$. After dissipation of excess pore water pressure it started to change the intermediate principal stress parameter $b$ to value equals 0.5 , because this value of this parameter allows to keep plane strain conditions (Zdravković and Jardine 2001). The next step was to change the angle of the rotation of principal stress directions $\alpha$. For particular samples the values of the angle of rotation of principal stress directions $\alpha$ were changed to $0^{\circ}, 30^{\circ}, 45^{\circ}, 60^{\circ}$ or $90^{\circ}$. Then followed the process of shearing the sample, which was carried out at the stress path involving the increase in deviator stress $(q)$ and constant value of effective mean stress $\left(p^{\prime}\right)$. During shearing constant values of the intermediate principal stress parameter $b$ and the angle of the rotation of principal stress directions $\alpha$ were kept.

\section{RESULTS AND DISCUSSION}

Based on the research performed in the Hollow Cylinder Apparatus basic characteristics were as follows (Figs. 4-8):
- deviator stress versus angle of the rotation of principal stress directions,

- deviator stress versus axial strain,

- principal effective stress ratio versus axial strain,

- pore pressure change versus axial strain,

- effective stress paths in relation to the axes q-p'.

In order to determine the undrained shear strength three criteria of the sample failure were used (Figs. 5-8):

- maximum deviator stress, $q$,

- maximum effective principal stress ratio, $\sigma_{1}^{\prime} / \sigma_{3}^{\prime}$,

- maximum increase in pore water pressure, $\Delta u$.

The research allowed to determine the values of undrained shear strength and the normalized values of undrained shear strength as well as the corresponding axial strains based on the three criteria of the sample failure (Table 2).

The test results in the Hollow Cylinder Apparatus show that the maximum values of the effective principal stress ratio in each test were near the

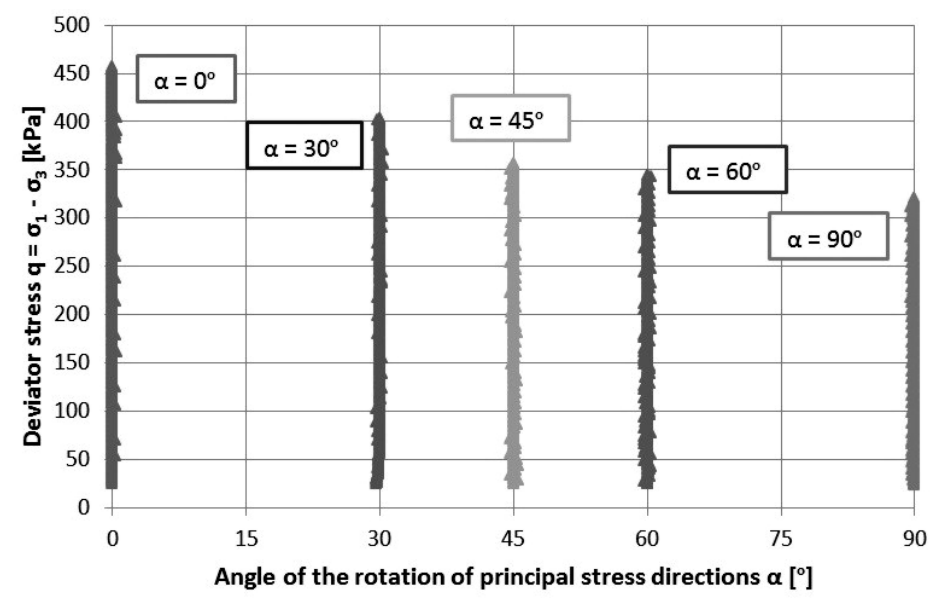

FIGURE 4. Deviator stress versus angle of the rotation of principal stress directions 

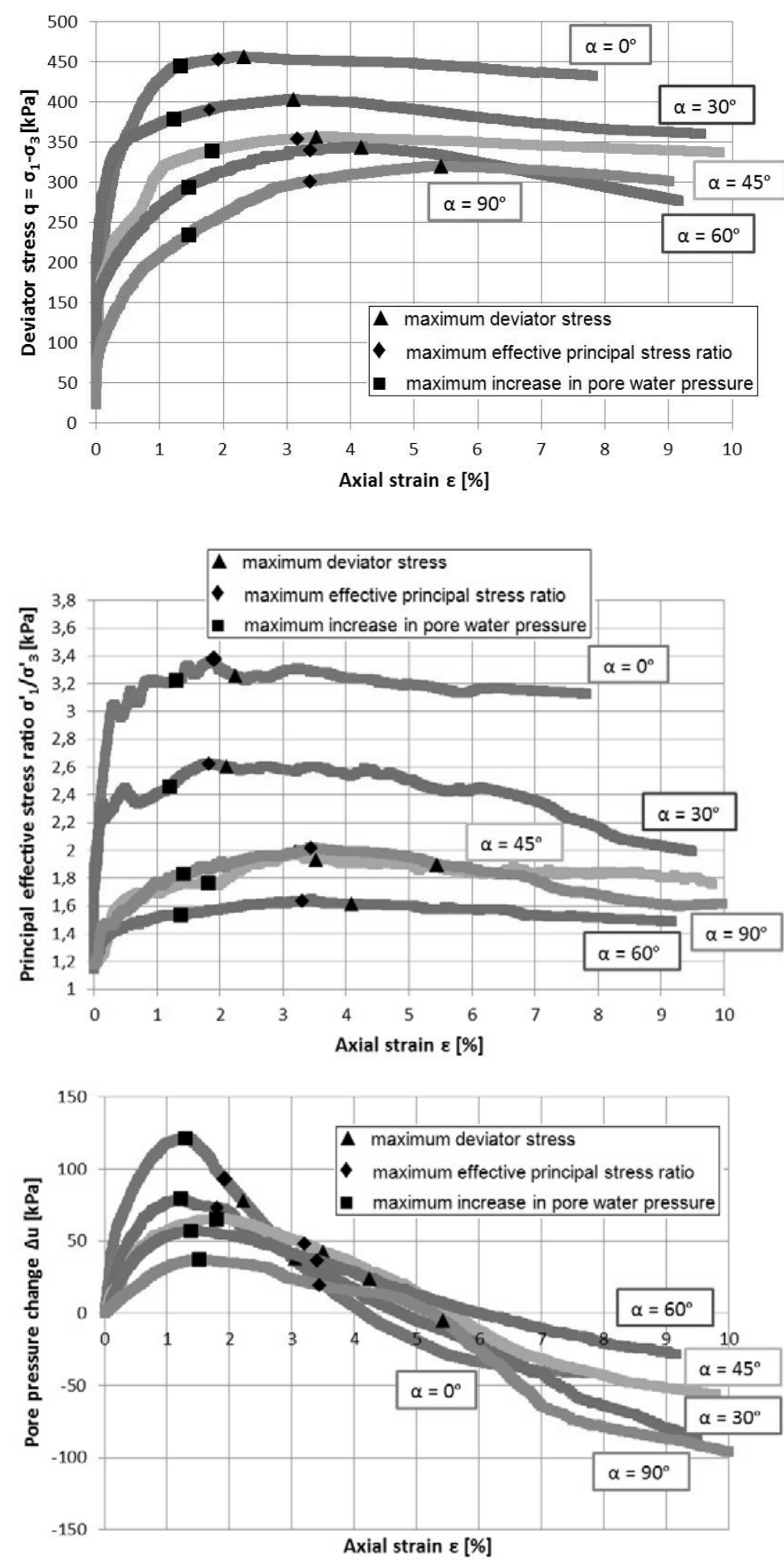

FIGURE 5. Deviator stress versus axial strain
FIGURE 6. Principal effective stress ratio versus axial strain
FIGURE 7. Pore pressure change versus axial strain 


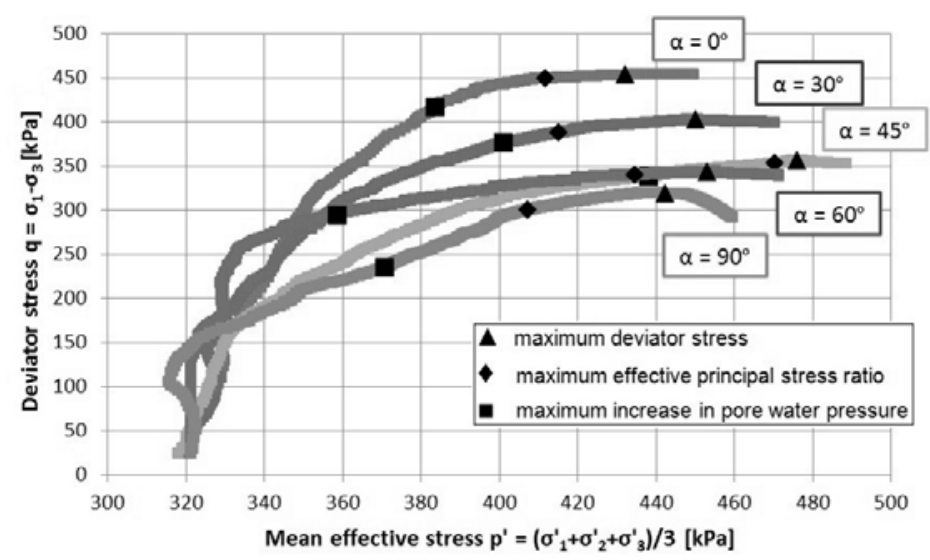

FIGURE 8. Effective stress paths in relation to the axes q-p'

TABLE 2. The results of HCA tests

\begin{tabular}{|c|c|c|c|c|}
\hline $\begin{array}{c}\text { Angle } \\
\text { of rotation } \\
\text { of principal } \\
\text { stress directions } \\
\alpha\left[^{\circ}\right]\end{array}$ & Failure criterion & $\begin{array}{l}\text { Undrained shear } \\
\text { strength } \\
\tau_{f u}[\mathrm{kPa}]\end{array}$ & $\begin{array}{c}\text { Normalized } \\
\text { undrained shear } \\
\text { strength } \\
\tau_{f u} / \sigma^{\prime}{ }_{v o}[-] \\
\sigma_{v o}{ }^{\prime}=310 \mathrm{kPa}\end{array}$ & $\begin{array}{c}\text { Axial strain } \\
\text { at failure } \\
\varepsilon[\%]\end{array}$ \\
\hline \multirow{3}{*}{0} & $\operatorname{Max} q$ & 228.5 & 0.74 & 2.2 \\
\hline & $\operatorname{Max} \sigma_{1}^{\prime} / \sigma^{\prime}{ }_{3}$ & 226.1 & 0.73 & 1.9 \\
\hline & $\operatorname{Max} \Delta u$ & 223.3 & 0.72 & 1.3 \\
\hline \multirow{3}{*}{30} & $\operatorname{Max} q$ & 201.8 & 0.65 & 3.1 \\
\hline & $\operatorname{Max} \sigma_{1}^{\prime} / \sigma_{3}^{\prime}$ & 195.3 & 0.63 & 1.8 \\
\hline & $\operatorname{Max} \Delta u$ & 189.8 & 0.61 & 1.2 \\
\hline \multirow{3}{*}{45} & $\operatorname{Max} q$ & 178.5 & 0.58 & 3.5 \\
\hline & $\operatorname{Max} \sigma_{1}^{\prime} / \sigma_{3}^{\prime}$ & 177.4 & 0.57 & 3.2 \\
\hline & $\operatorname{Max} \Delta u$ & 169.9 & 0.55 & 1.8 \\
\hline \multirow{3}{*}{60} & $\operatorname{Max} q$ & 172.4 & 0.56 & 4.3 \\
\hline & $\operatorname{Max} \sigma_{1}{ }_{1} / \sigma_{3}$ & 170.2 & 0.55 & 3.5 \\
\hline & $\operatorname{Max} \Delta u$ & 145.4 & 0.47 & 1.5 \\
\hline \multirow{3}{*}{90} & $\operatorname{Max} q$ & 160.1 & 0.52 & 5.4 \\
\hline & $\operatorname{Max} \sigma_{1}^{\prime} / \sigma_{3}^{\prime}$ & 151.2 & 0.49 & 3.4 \\
\hline & $\operatorname{Max} \Delta u$ & 118.1 & 0.38 & 1.5 \\
\hline
\end{tabular}

maximum values of the deviator stress, and the maximum values of pore pressure change followed much earlier. During each test the maximum effective principal stress ratio occurred earlier than the maximum deviator stress. Axial strains corresponding to the maximum values of particular failure criteria are in the range $1.2-5.4 \%$, so they can be considered as safe. Head (1986) proved that 
$20 \%$ is the maximum value of the axial strain beyond which the reliability of the results decreases.

The highest values of undrained shear strength were obtained by taking as a failure criterion maximum deviator stress, and the lowest ones were obtained assuming maximum pore pressure change as a failure criterion. The difference in determined values of undrained shear strength is the smallest at $\alpha=0^{\circ}$ and is equal to $5.2 \mathrm{kPa}$, while at $\alpha=90^{\circ}$ is the largest and is equal to $42 \mathrm{kPa}$.

Results of the research show that the values of the normalized undrained shear strength of cohesive soil with OCR equals 4 and $I_{p}$ about $77 \%$ decrease with increasing the angle of the rotation of principal stress directions. Taking as a failure criterion maximum deviator stress and maximum principal effective stress ratio the decrease in normalized undrained shear strength is similar. Using as a failure criterion the maximum pore pressure change the decrease in undrained shear strength is similar to other criteria for angle $\alpha$ between $0^{\circ}$ and $45^{\circ}$.
For angles above $45^{\circ}$ the decrease in undrained shear strength is higher than for other criteria (Fig. 9).

Assuming the maximum deviator stress as a failure criterion, the normalized undrained shear strength is about $22 \%$ less for the test at angle $\alpha=45^{\circ}$ and about $30 \%$ less at angle $\alpha=90^{\circ}$ than for the test at angle $\alpha=0^{\circ}$. Based on the performed tests it can be seen that the higher decrease in undrained shear strength occurs for angles between $0^{\circ}$ and $45^{\circ}$, while for angles above $45^{\circ}$ the decrease in undrained shear strength is less.

The values of undrained shear strength at various angles of the rotation of principal stress directions obtained from tests in HCA allow to determine the values of empirical coefficients used in Ladd's equation. For the angle $\alpha=0^{\circ}$ (TC) value of parameter $S$ is equal to 0.30 and parameter $m$ is equal to 0.65 while for the angle $\alpha=45^{\circ}$ (DSS) value of $S$ is equal to 0.25 and $m$ is equal to 0.61 . For the angle $\alpha=90^{\circ}$ (TE) value of parameter $S$ is equal to 0.26 and parameter $m$ is equal to 0.50 .

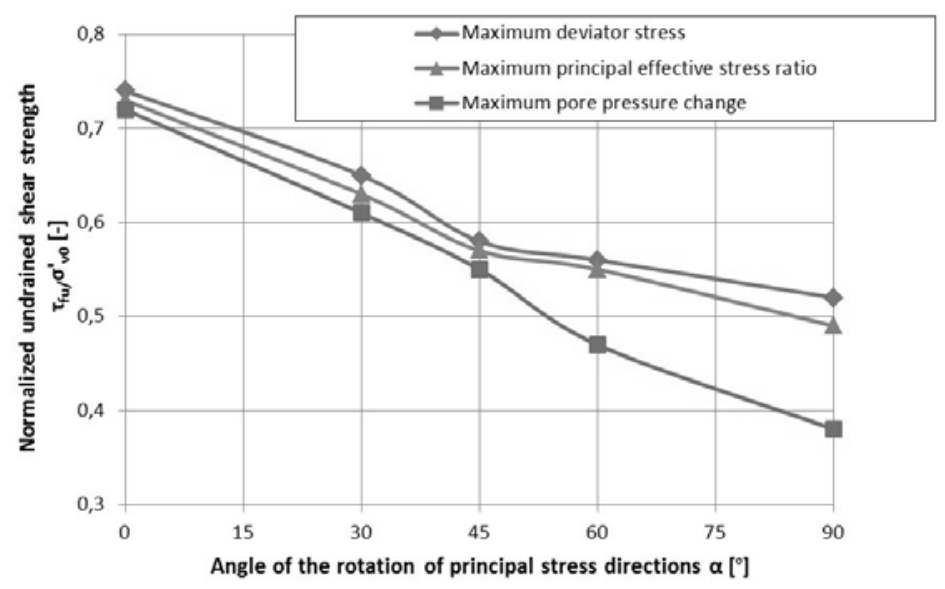

FIGURE 9. Change in normalized undrained shear strength depending on the angle of the rotation of principal stress directions 


\section{CONCLUSIONS}

The problem of the rotation of principal stress directions, although very important, is most often left out during determination of the undrained shear strength of subsoil. The influence of the rotation of principal stress directions on strength parameters is often discussed in literature, but it is not still clearly shown the way how to take into account its influence on the capacity of the subsoil.

The research in the Hollow Cylinder Apparatus on natural clay with overconsolidation ratio (OCR) equals 4 and plasticity index $\left(I_{p}\right)$ about $77 \%$ showed that the value of the normalized undrained shear strength decreases with increasing angle of rotation of principal stress directions. For tested soil, assuming the maximum deviator stress as a failure criterion, the normalized undrained shear strength is about $22 \%$ less for the test at angle $\alpha=45^{\circ}$ and about $30 \%$ less at angle $\alpha=90^{\circ}$ than for the test at angle $\alpha=0^{\circ}$.

Performed tests in HCA allow to determine the values of empirical coefficients used in Ladd's equation describing the undrained shear strength distribution.

In order to determine the influence of overconsolidation ratio (OCR) and plasticity index $\left(I_{p}\right)$ on the normalized undrained shear strength further investigations should be done.

\section{REFERENCES}

BJERRUM L. 1973: Problems of soil mechanics and construction on soft clays and structurally unstable soils (collapsible, expansive and others. Proc. of $8^{\text {th }}$ International Conference Soil Mechanics Foundation Engineering, Moscow: 111-159.
HEAD K.H. 1986: Manual of soil laboratory testing. John Wiley \& Sons, New York.

HIGHT D.W., GENS A., SYMES M.J. 1983: The development of a new hollow cylinder apparatus for investigating the effects of principal stress rotation in soils. Géotechnique 33 (4): 335-383.

JARDINE R.J., MENKITI C.O. 1999: The undrained anisotropy of $\mathrm{K}_{0}$ consolidated sediments. In: Geotechnical Engineering for Transportation Infrastructure. Balkema, Rotterdam: 1101-1108.

JARDINE R.J., SMITH P.R. 1991: Evaluating design parameters for multi-stage construction. Proc. of International Conference on Geotechnical Engineering for Coastal Development, Yokosuka: 197-202.

KIZIEWICZ D., LECHOWICZ Z. 2013: Anizotropia wytrzymałości na ścinanie bez odpływu gruntów spoistych w cylindrycznym aparacie skrętnym [Testing of undrained shear strength in Hollow Cylinder Apparatus]. Civil and Environmental Engineering 4 (2): 119-126 [in Polish].

LADD C.C. 1985: Stability evaluation for staged construction. Proc. for MIT Special Summer Course 1.60s. Lecture 15.

LIN H., PENUMADU D. 2005: Experimental Investigation on Principal Stress Rotation in Kaolin Clay. Journal of Geotechnical and Geoenvironmental Engineering. ASCE 131 (5): 633-642.

LIPIŃSKI M.J., WDOWSKA M. 2010: Saturation criteria for heavy overconsolidated cohesive soils. Annals of Warsaw University of Life Sciences - SGGW. Land Reclamation 42(2): 295-302.

MOLENKAMP F. 1998: Principle of axial shear apparatus. Géotechnique 48 (3): 427-431.

NEHER H.P., CUDNY M., WILTAFSKY C., SCHWEIGER H.F. 2002: Modelling principal stress rotation effects with multilaminate type constitutive models for clay. Proc. of $8^{\text {th }}$ International Symposium on Numerical Models in Geomechanics, Rome: 41-47. 
NISHIMURA S. 2005: Laboratory study on anisotropy of natural London Clay. Ph.D. Thesis. Imperial College London.

NISHIMURAS., MINHN.A., JARDINE R.J. 2007: Shear strength anisotropy of natural London Clay. Géotechnique 57 (1): 49-62.

WRZESIŃSKI G., LECHOWICZ Z. 2012: Analiza zachowania się podłoża organicznego obciążonego etapowo budowanym nasypem [Analysis of the behaviour of organic subsoil loaded by stage-constructed embankment]. Inżynieria Morska i Geotechnika 4: 487-491 [in Polish].

ZDRAVKOVIĆ L., JARDINE R.J. 2001: The effects on anisotropy of rotating the principal stress axes during consolidation. Géotechnique 51 (1): 69-83.

ZDRAVKOVIĆ L., POTTS D.M., HIGHT D.W. 2002: The effect of strength anisotropy on the behavior of embankments on soft ground. Géotechnique 52 (6): 447-457.

Streszczenie: Wpływ zmiany kierunków naprężeń głównych na wytrzymałość na ścinanie bez odpływu. W artykule przedstawiono wyniki badań przeprowadzonych $\mathrm{w}$ cylindrycznym aparacie skrętnym HCA (Hollow Cylinder Apparatus) na próbkach gruntu spoistego o nienaruszonej struk- turze. Celem badań było wyznaczenie wartości wytrzymałości na ścinanie bez odpływu przy różnych wartościach kąta obrotu kierunków naprężeń głównych. Badania przeprowadzono na próbkach gruntu pochodzacych z terenu budowy stacji Centrum Nauki Kopernik II linii metra w Warszawie o współczynniku prekonsolidacji (OCR) równym 4 i wskaźniku plastyczności $\left(I_{p}\right)$ około $77 \%$. Badania wykonano z konsolidacją anizotropową oraz ścinaniem w warunkach bez odpływu. Uzyskane wyniki pozwoliły ocenić wpływ zmiany kierunków naprężeń głównych na wartość wytrzymałości na ścinanie bez odpływu.

Słowa kluczowe: wytrzymałość na ścinanie bez odpływu, cylindryczny aparat skrętny, grunty spoiste, kierunki naprężeń głównych

MS. received in December 2013

\section{Authors' address:}

Wydział Budownictwa i Inżynierii Środowiska SGGW

Katedra Geoinżynierii

ul. Nowoursynowska 159, 02-776 Warszawa

Poland

e-mail: grzegorz_wrzesinski@sggw.pl zbigniew_lechowicz@sggw.pl 